\title{
Composition of the bacterial community degrading Phaeocystis mucopolysaccharides in enrichment cultures
}

\author{
Ingmar Janse ${ }^{1, *}$, Gabriel Zwart ${ }^{2}$, Marc J. E. C. van der Maarel ${ }^{1}{ }$ Jan C. Gottschal $^{1}$ \\ ${ }^{1}$ Department of Microbiology, University of Groningen, Kerklaan 30, 9751 NN Haren, PO Box 14, 9750 AA Haren, \\ The Netherlands \\ ${ }^{2}$ Department of Microbial Ecology, Centre for Limnology, Netherlands Institute of Ecology, Rijksstraatweg 6, \\ Nieuwersluis, PO Box 1299, 3600 BG Maarssen, The Netherlands
}

\begin{abstract}
As described recently (Janse et al. 1999; Limnol Oceanogr 44(6):1447-1457), mucopolysaccharides of the marine microalga Phaeocystis can be degraded in enrichment cultures. In this paper we report on the characterization of the microbial community in such enrichments. Denaturing gradient gel electrophoresis (DGGE) profiles that were obtained during mucopolysaccharide degradation showed a substantial number of sequence types, suggesting the occurrence of multiple bacterial species in the enrichments. Only after the rate of mucopolysaccharide degradation had slowed down to less than $5 \%$ of its initial value could a significant change in the relative abundance of certain bacterial species in the enrichments be detected. Therefore, degradation of this complex substrate does not seem to require a succession of bacterial populations. Several mucopolysaccharide-degrading enrichments obtained by inoculation from different sources (colony mucus, the water column and sediments), and grown under either oxic or anoxic conditions, appeared to contain very different microbial communities with only a few overlapping species. Therefore, the selection pressure imposed by mucopolysaccharides as growth substrates is only one of the factors shaping the species composition in the enrichments. Attempts to isolate pure cultures of bacteria capable of mucopolysaccharide degradation using plating and dilution techniques failed. However, following a new approach which couples community analysis (using DGGE) and the physiological capability of the enrichment to degrade mucopolysaccharides, bacteria involved in the degradation process could be identified. This was based on the correlation between inhibition of mucopolysaccharide degradation and absence of certain bands from DGGE profiles when enrichment cultures were incubated at an elevated temperature. Phylogenetic analysis on clones of DNA fragments that were excised from DGGE gels, placed the putative mucopolysaccharide degraders in the $\alpha$ and $\gamma$ subdivisions of the Proteobacteria, the Cytophaga-Flexibacter cluster, and the Planctomyces and Verrucomicrobiales clade. These findings directly link representatives of these abundant bacterial clusters with the degradation of complex algal polymers in the sea.
\end{abstract}

KEY WORDS: Phaeocystis · Mucopolysaccharide degradation · Enrichment cultures · Microbial community $\cdot$ DGGE $\cdot$ Dynamics $\cdot$ Identification

\section{INTRODUCTION}

Most organic material in the oceans originates from primary production by phytoplankton (Lalli \& Parsons

${ }^{*}$ Present address: Department of Microbial Ecology, Centre for Limnology, Netherlands Institute of Ecology, Rijksstraatweg 6, Nieuwersluis, PO Box 1299, 3600 BG Maarssen, the Netherlands. E-mail: janse@cl.nioo.knaw.nl
1993). This material constitutes a vast resource of reduced carbon, which is predominantly recycled in the water column, where it is used as energy and a carbon source for the marine food web. In general, at the basis of the food web, particulate organic matter is taken up by grazers, while dissolved organic matter (DOM) is utilized by bacteria. Alternatively, organic matter may aggregate, sink and become buried in the sediment, or it may end up in the DOM pool for an 
extended period (Williams \& Druffel 1987, Druffel et al. 1992). The relative importance of each of these alternative pathways (grazing food chain, microbial loop, sedimentation, DOM storage) depends on the interactions of the complex pool of organic matter with various organisms in the marine food web.

On average, one-half of the oceanic primary production passes through the microbial loop (Fuhrman \& Azam 1982, Cole et al. 1988, Hagström et al. 1988, Fuhrman 1992), but this figure varies widely under different environmental circumstances. In extreme cases, local conditions may prevent the flow of any primary production through the microbial loop, whereas under other circumstances all primary produced matter may be utilized by bacteria (Azam et al. 1995). Obviously the contribution of the microbial loop will strongly depend on the capabilities of heterotrophic bacteria to process primary produced organic matter, which are therefore a critical factor in oceanic carbon cycling.

A significant portion of the DOM that is potentially available for bacteria is polymeric (Sugimura \& Suzuki 1988, Benner et al. 1992, Azam et al. 1995), requiring partial hydrolysis before fragments are small enough to be taken up by bacteria. However, a large fraction of this material, e.g. algal structural polymers, is of a complex nature and may not be readily degradable. But, as the marine carbon-cycle needs to be balanced to prevent rapid build-up of organic matter, it must be assumed that for every biologically formed compound microorganisms exist with the ability to degrade it either completely or at least partially. The fragments that are first formed can subsequently be utilized by other organisms. The exact degradation pattern of complex organic matter depends on the compositional and structural features of the polymers and on the micro-organisms involved in the breakdown process. From earlier studies on the degradation of recalcitrant polymeric substances it is known that the activity of specialists, possessing enzyme systems for the primary hydrolysis of such compounds, is succeeded frequently by that of other microbes which can only utilize the hydrolysis products. Such cooperation of micro-organisms has been extensively investigated for the breakdown of substances such as cellulose, lignin and proteins (Rheinheimer 1992, Schlegel 1995, Warren 1996).

An interesting and substantial source of heterogeneous polymers in the marine environment is formed by the heteropolysaccharides excreted by the marine microalga Phaeocystis (Lancelot \& Mathot 1987, Janse et al. 1996, 1999). Phaeocystis cells excrete large amounts of complex carbohydrates (mucopolysaccharides) that form a mucous matrix embedding the cells. Cells and mucus are organized as hollow colonies that often dominate the ecosystem during large spring blooms (Lancelot et al. 1987, Davidson \& Marchant 1992, van Boekel 1993, van Rijssel et al. 1997). The mucous material appears to resist degradation, at least to a certain extent, as indicated by the observation that after algal blooms a significant fraction sinks to the sediment or ends up as foam on the beach (Lancelot \& Rousseau 1994, Riebesell et al. 1995, Hong et al. 1997).

Recently, we showed that the Phaeocystis mucopolysaccharides can indeed be degraded in enrichment cultures (Janse et al. 1999). However, the rate of degradation gradually decreased during breakdown of the polymer. It was concluded that production of inhibitors rather than progressive changes in composition of the mucopolysaccharide was the likely cause of this decreased degradation rate. Although this study successfully explored the degradation of Phaeocystis mucopolysaccharides by enriched microbial communities, what has remained totally obscure is the identity and population dynamics of the members of these microbial communities that are responsible for degradation. Insight into these microbial communities is needed to reveal whether the presence of specific (consortia of) bacteria is required for mucopolysaccharide degradation, i.e. whether there is a distinguishable bacterial community adapted to mucopolysaccharide degradation and therefore correlated to Phaeocystis blooms. Furthermore, the dynamics in the microbial community could yield information regarding the complexity of the degradation process, e.g. the occurrence of successive phases of breakdown. All our efforts to obtain pure cultures of bacteria capable of mucopolysaccharide degradation using plating and dilution techniques have failed so far. But, even enrichment cultures may be used to identify the mucopolysaccharide degraders by making use of the strict relationship between the presence of certain bacteria within the enrichment and the occurrence of mucus degradation. This approach requires the use of techniques that allow detection and identification of individual populations in mixed cultures.

Here, we report on the use of denaturing gradient gel electrophoresis (DGGE) to study the diversity and dynamics of the microbial community degrading Phaeocystis mucopolysaccharides, and to identify the bacteria responsible for degradation. This technique provides information about sequence variation in a mixture of polymerase chain reaction (PCR) fragments of identical size. Hence, after DNA extraction and specific amplification of partial 16S rRNA gene fragments, differences in the composition of microbial communities can be revealed. Moreover, subsequent sequencing of selected 16S rRNA gene fragments allows phylogenetic identification of the corresponding bacteria. 


\section{MATERIALS AND METHODS}

Preparation of partially purified mucus solution. Phaeocystis biomass was collected by dragging a plankton net (100 $\mu \mathrm{m}$ mesh size) through a dense $P$. globosa bloom $\left(>50 \times 10^{6}\right.$ cells $\left.^{-1}\right)$ just below the water surface during the 1994 spring bloom in the North Sea off the Texel coast, The Netherlands $\left(53^{\circ} 11^{\prime} \mathrm{N}\right.$, $4^{\circ} 22^{\prime} \mathrm{E}$ ). Immediately after harvest the mucous biomass was stored at $-20^{\circ} \mathrm{C}$. After thawing, solubilization of the material was increased using a tissue homogenizer and heating at $80^{\circ} \mathrm{C}$ for $2 \mathrm{~h}$. Non-soluble material was removed by centrifugation $(1 \mathrm{~h}$ at $29000 \times g)$ and the protein present in the supernatant was digested for $3 \mathrm{~h}$ at $40^{\circ} \mathrm{C}$ at $\mathrm{pH} 7.5$ using $25 \mu \mathrm{g} \mathrm{ml}^{-1}$ pronase E from Streptomyces griseus (Fluka Biochemika). This solution was dialyzed against 20 volumes of demineralized water at $4^{\circ} \mathrm{C}$, which was replaced 8 times during $4 \mathrm{~d}$, using dialysis tubing $(\varnothing 15 \mathrm{~mm})$ with pore size 6 to 8 kD (Spectra/Por, Spectrum Medical Industries, Inc., Houston, Texas). Before storage, mucus solutions were heat-sterilized $\left(121^{\circ} \mathrm{C}\right.$ for $\left.20 \mathrm{~min}\right)$ after addition of $3 \%$ $\mathrm{NaCl}$. Heat-sterilization did not affect the monosaccharide composition or the average chain length of mucopolysaccharides (see Janse et al. 1999).

Media. Medium composition was adapted from Veldhuis \& Admiraal (1987). For growth under oxic conditions a buffered basal salt medium was used containing (concentrations in $\mathrm{g} \mathrm{l}^{-1}$ deionized water): $\mathrm{NaCl}$ (24.5); $\mathrm{MgCl}_{2} \cdot 6 \mathrm{H}_{2} \mathrm{O}(9.8)_{i} \mathrm{Na}_{2} \mathrm{SO}_{4}$ (3.2); $\mathrm{CaCl}_{2} \cdot 2 \mathrm{H}_{2} \mathrm{O}$ $(0.53) ; \mathrm{K}_{2} \mathrm{SO}_{4}(0.85) ; \mathrm{Na}_{2} \mathrm{HPO}_{4}(0.04) ; \mathrm{NH}_{4} \mathrm{Cl} \quad(0.5)$; $\mathrm{NaHCO}_{3}(0.2)$; minor salts solution $\left(2 \mathrm{ml} \mathrm{l}^{-1}\right)$; trace elements solution $\left(2 \mathrm{ml} \mathrm{l}^{-1}\right)$; vitamin solution $\left(1 \mathrm{ml} \mathrm{l}^{-1}\right)$; tris(hydroxymethyl)methylamine (Tris) $\mathrm{HCl}$ pH 7.5 $\left(5 \mathrm{ml} \mathrm{l}^{-1}\right)$. Ammonium, phosphate, bicarbonate, minor salts and trace element solutions were autoclaved separately and added as small, concentrated volumes to the autoclaved basal salts after cooling to room temperature. The vitamin solution was filter sterilized and added separately after autoclaving. The minor salt solution contained the following (concentrations in $\mathrm{g} \mathrm{l}^{-1}$ deionized water): $\mathrm{KBr}(22) ; \mathrm{SrCl} \cdot 6 \mathrm{H}_{2} \mathrm{O}$ (6.39); $\mathrm{AlCl}_{3}(0.028) ; \mathrm{H}_{3} \mathrm{BO}_{3}(0.4) ; \mathrm{RbCl}(0.061) ; \mathrm{LiCl}(0.006) ;$ $\mathrm{KI}(0.02)$. The trace element solution contained the following (concentrations in $\mathrm{g} \mathrm{l}^{-1}$ deionized water): $\mathrm{FeCl}_{3} \cdot 6 \mathrm{H}_{2} \mathrm{O}$ (3.15); $\mathrm{Na}_{2}$ EDTA $2 \mathrm{H}_{2} \mathrm{O}$ (4.82); $\mathrm{CoCl}_{2} \cdot 6 \mathrm{H}_{2} \mathrm{O}$ (0.01); $\quad \mathrm{MnCl}_{2} \cdot 4 \mathrm{H}_{2} \mathrm{O} \quad(0.18) ; \quad \mathrm{Na}_{2} \mathrm{MoO}_{4} \cdot 2 \mathrm{H}_{2} \mathrm{O} \quad(0.006)$; $\mathrm{CuSO}_{4}(0.007) ; \mathrm{ZnSO}_{4} \cdot 7 \mathrm{H}_{2} \mathrm{O}(0.022)$. The vitamin solution was adapted from Schut et al. (1993) (concentrations in $\mu \mathrm{g} \mathrm{l}^{-1}$ deionized water): $\mathrm{p}$-aminobenzoic acid (50); pyridoxine- $\mathrm{HCl}(100)$; thiamine- $\mathrm{HCl}(50)$; riboflavine (50); nicotinic acid (50); D-Ca-panthothenate (50); lipoic acid (50); nicotinamide (50); vitamin B12 (50); biotine (20); folic acid (20). No buffer was added when the enrichment culture was sampled for (total organic carbon) TOC measurements. For anoxic medium the concentration of $\mathrm{CaCl}_{2} \cdot 2 \mathrm{H}_{2} \mathrm{O}$ in the basal salt medium was reduced from 0.53 to $0.1 \mathrm{~g} \mathrm{l}^{-1}$. An anoxic bicarbonate solution of $84 \mathrm{~g} \mathrm{l}^{-1} \mathrm{NaHCO}_{3}$ and an anoxic sulphide solution of $39 \mathrm{~g} \mathrm{l}^{-1} \mathrm{Na}_{2} \mathrm{~S}$ were prepared in boiled and then cooled deionized water, and were subsequently autoclaved and stored under $\mathrm{N}_{2} /$ $\mathrm{CO}_{2}(80 / 20 \%)$. The concentrated ammonium solution, resazurin $(0.0001 \%)$ and yeast extract $(0.01 \%)$ were added to the basal salt medium, flushed with $\mathrm{N}_{2} / \mathrm{CO}_{2}$ $(80 / 20 \%)$ at $80^{\circ} \mathrm{C}$ and autoclaved. After cooling to room temperature, the concentrated phosphate solution, minor salt solution, trace element solution, vitamin solution, anoxic bicarbonate solution $\left(30 \mathrm{ml} \mathrm{l}^{-1}\right)$, and sulphide solution $\left(1 \mathrm{ml} \mathrm{l}^{-1}\right)$ were added under aseptic and anoxic conditions. The basal salt solution was provided with a carbon source (a solution of partially purified mucus or of yeast extract), before addition of the medium components mentioned above.

Growth and sampling. Aerobic enrichment cultures were grown in cotton-plugged Erlenmeyer flasks (medium volume $\leq 20 \%$ of the maximum Erlenmeyer volume) or culture tubes ( $5 \mathrm{ml}$ medium in $20 \mathrm{ml}$ tubes), which were incubated statically at $12^{\circ} \mathrm{C}$. Hungate anaerobic techniques were used for anaerobic enrichment cultures. Partially purified mucus was added to seawater medium to obtain a starting concentration of approximately $2 \mathrm{mM}$ glucose equivalents (measured by the phenol-sulphuric acid method, see 'Analytical procedures' below); this concentration was chosen to ensure sufficiently high mucopolysaccharide concentrations throughout mucus degradation for application of the various analytical procedures. At regular intervals the cultures were vortexed and samples were withdrawn aseptically. Bacteria were collected by filtration on a $0.2 \mu \mathrm{m}$ polycarbonate filter or by centrifugation $(15 \mathrm{~min}$ at $8000 \times g)$. When appropriate, the supernatant was stored at $-20^{\circ} \mathrm{C}$ for further analysis. The occurrence of mucopolysaccharide degradation was assessed by following changes in the total carbohydrate concentration in the culture medium (using the phenol-sulphuric acid method).

Enrichment cultures from various inocula. In order to obtain stable mucopolysaccharide-degrading enrichment cultures, inocula taken in 1996 were incubated with medium containing the partially purified mucus described above as the carbon source. The stable enrichment culture that was used for most experiments (see Figs. 1, 3A \& 4A) had originally been inoculated with bacteria from seawater collected on May 8, 1996 (declining spring bloom) in the Marsdiep (Dutch Wadden Sea). The enrichment used for Figs. 3B \& 4B originated from an inoculum prepared from seawater obtained on May 21, 1996 (during spring bloom) in the Balsfjord (Norway). 
The enrichment cultures that were used in Fig. 2 originated from seawater inocula obtained in the Marsdiep on April 24, 1996 (peak of bloom) for lane 1, and on May 8, 1996 (declining bloom) for lane 3, and in the Balsfjord on April 30, 1996 (during spring bloom) for lane 4. To prepare the inocula (lanes 1, 3, and 4), bacteria from $100 \mathrm{ml}$ seawater that had been collected in sterile flasks were harvested by centrifugation $(15 \mathrm{~min}$ at $8000 \times g)$. After resuspension in $2.5 \mathrm{ml}$ of the supernatant they were filtered (Whatman GF/F) to minimize the number of protozoa and transferred to $25 \mathrm{ml}$ sterile seawater medium containing partially purified mucus.

Enrichment cultures inoculated with bacteria from sediment were obtained on June 28, 1996 (after bloom), from intertidal sediments covered by microbial mats at 2 distinct locations near the island Schiermonnikoog (Wadden Sea, The Netherlands) for lanes 5 and 6, and April 30 and May 2 from bottom sediment (175 $\mathrm{m}$ depth) in the Balsfjord for lanes 2, 7 and 8. To obtain aerobic bacteria from sediment (lane 2), approximately $10 \mathrm{ml}$ of sediment was mixed with 2 volumes of sterile seawater medium, extensively shaken, and the resulting slurry filtered through Whatman GF/F. An aliquot of $2.5 \mathrm{ml}$ of this filtrate was used to inoculate $25 \mathrm{ml}$ of sterile seawater medium containing partially purified mucus. For anaerobic bacteria (lanes 5 to 8), $10 \mathrm{ml}$ of sediment was mixed with 2 volumes of anoxic (autoclaved) seawater while kept under an $\mathrm{N}_{2} / \mathrm{CO}_{2}$ $(80 / 20 \%)$ atmosphere. Without prior filtration, $1.5 \mathrm{ml}$ of this slurry was used to inoculate $13.5 \mathrm{ml}$ anoxic sterile seawater medium containing partially purified mucus.

Isolations. Stable enrichment cultures were diluted to extinction through successive transfers of $0.4 \mathrm{ml}$ culture in $3.6 \mathrm{ml}$ seawater medium with partially purified Phaeocystis mucus as the carbon source. Mucus degradation was monitored by measurements of the total carbohydrate concentration in the supernatant after 0 , 1, 3 and $6 \mathrm{wk}$. For isolations on plates, different types of solid media were prepared. Seawater medium was supplemented with either a mixture of monosaccharides (arabinose, xylose, ribose, rhamnose, manose, galactose, glucose and glucuronic acid; $0.1 \mathrm{mM}$ each) and disaccharides (cellobiose and maltose; $0.5 \mathrm{mM}$ each), or with mucus (approx. $2 \mathrm{mM}$ glucose equivalents measured by the phenol-sulphuric acid method, see 'Analytical procedures' below) as the carbon source. This medium was solidified with $1.8 \%$ noble agar (Difco), which had been washed as described by Schut et al. (1993), $2 \%$ gellan gum (gelrite, Sigma chemical Co.) or with silica (silica gel 100 to 200 mesh, Sigma chemical Co.) prepared as described by Gerhardt et al. (1994). Bacteria from mucopolysaccharidedegrading enrichment cultures were streaked on these plates. Occasionally, diluted cultures were mixed with equal volumes of medium containing $0.8 \%$ agar and poured over plates containing $2 \%$ agar to obtain colonies in $0.4 \%$ 'soft agar'. Colonies of different morphology that had developed on or in the agar medium were transferred to medium containing partially purified Phaeocystis mucus. The carbohydrate concentration in the supernatant of these cultures was monitored for $6 \mathrm{wk}$.

Analytical procedures. Total carbohydrate concentrations were routinely determined as glucose equivalents by the modified phenol-sulphuric acid method described by Liu et al. (1973) using glucose as a standard. In this colorimetric method, the response of different types of monosaccharides varies. As a result, the concentration of mucus measured using this method (expressed in glucose equivalents) is an underestimation of the actual concentration. The underestimation was determined to be $40 \%$ or less of the added concentration in preliminary experiments with defined mixtures of polysaccharides known to be present in the mucus. TOC was measured on a Shimadzu TOC-500 analyzer (Shimadzu Benelux, 's Hertogenbosch, The Netherlands) with sodium biphthalate as a standard.

DGGE profiling. For DGGE analysis, samples (1 ml) from mucopolysaccharide-degrading enrichment cultures collected during breakdown, and from various enrichments that differed with respect to the origin of their inoculum (see Figs. 1B \& 2 respectively), were used. Bacteria from these samples were collected on $0.2 \mu \mathrm{m}$ polycarbonate filters and stored at $-80^{\circ} \mathrm{C}$. After thawing the filters, DNA isolation, PCR amplification using universal eubacterial (341 forward and 518 reverse with a GC-rich clamp) (Muyzer et al. 1993) and DGGE analysis were done as described by Zwart et al. (1998). An $8 \%$ (w/v) polyacrylamide gel with a linear gradient ranging from 30 to $60 \%$ of denaturant was used $(100 \%$ denaturant contained $7 \mathrm{M}$ urea and $40 \%$ formamide).

For DGGE analysis of mucopolysaccharide and yeast extract degrading enrichment cultures at different temperatures (see Fig. 4), the DNA isolation was done as follows: bacteria from $6 \mathrm{ml}$ culture samples were collected by centrifugation $(10 \mathrm{~min}$ at $10000 \times g$ ) and washed in cold $\left(4^{\circ} \mathrm{C}\right)$ phoshate buffer $(50 \mathrm{mM}, \mathrm{pH} 7)$ containing $25 \mathrm{~g} \mathrm{l}^{-1} \mathrm{NaCl}$ and $3 \mathrm{~g} \mathrm{l}^{-1} \mathrm{MgCl}_{2} \cdot 6 \mathrm{H}_{2} \mathrm{O}$. After resuspension of the pellet in $1.44 \mathrm{ml}$ Tris buffer (10 mM, pH 8) containing 1 mM EDTA, $60 \mu l$ lysozyme $(5 \%)$ was added and the suspension was incubated for $30 \mathrm{~min}$ at $37^{\circ} \mathrm{C}$. Subsequently, the protoplasts were lysed through addition of $200 \mu \mathrm{l}$ N-lauroylsarcosine $(10 \%), 35 \mu$ sodium dodecyl sulphate $(25 \%)$ and $10 \mu \mathrm{l}$ DNAse free RNAse $(50 \mu \mathrm{g}$ $\mathrm{ml}^{-1}$ ) and incubation for $30 \mathrm{~min}$ at $37^{\circ} \mathrm{C}$. Then $10 \mu \mathrm{l}$ proteinase $\mathrm{K}(2 \%)$ was added and the mixture was incubated for $30 \mathrm{~min}$ at $55^{\circ} \mathrm{C}$. Extraction and precipi- 
tation of the DNA from this mixture was performed according to Sambrook et al. (1989). PCR amplification was carried out as described by van der Maarel et al. (1998). The eubacterial primers used were those described by Muyzer et al. (1993). PCR conditions for amplification of DNA isolated from the enrichment cultures were as follows: after an initial denaturation step of $5 \mathrm{~min}$ at $95^{\circ} \mathrm{C}$, the temperature of the PCR mixture was lowered to $80^{\circ} \mathrm{C}$ and 1 to $2 \mathrm{U}$ of Taq DNA polymerase was added. Subsequently, in a touchdown protocol of 20 cycles, the DNA was denatured for $1 \mathrm{~min}$ at $94^{\circ} \mathrm{C}$, annealed for $1 \mathrm{~min}$, starting at $65^{\circ} \mathrm{C}$ and decreasing $0.5^{\circ} \mathrm{C}$ per cycle to $55^{\circ} \mathrm{C}$, and extended for $1 \mathrm{~min}$ at $72^{\circ} \mathrm{C}$. This was followed by 9 cycles, during which the annealing temperature was $55^{\circ} \mathrm{C}$. Finally the mixture was incubated for $4 \mathrm{~min}$ at $72^{\circ} \mathrm{C}$. The resulting PCR products were analyzed on an $8 \%$ (w/v) polyacrylamide gel with a linear gradient ranging from 40 to $55 \%$ denaturant (100\% denaturant contained $7 \mathrm{M}$ urea and $40 \%$ formamide).

DGGE fragment sequence analysis. DNA fragments were excised from the polyacrylamide gel using a sterile scalpel. DNA was extracted by incubation of crushed bands for $30 \mathrm{~min}$ at $95^{\circ} \mathrm{C}$ in an elution buffer as described by Sanguinetti et al. (1994). After centrifugation of polyacrylamide gel residues, $\mathrm{LiCl}$ was added to the supernatant to a final concentration of $0.4 \mathrm{M}$. The PCR products were precipitated in $70 \%$ ethanol for $3 \mathrm{~h}$ at $-80^{\circ} \mathrm{C}$ and subsequently washed with $80 \%$ ethanol. Subsequently, the purified PCR products were amplified using universal eubacterial primers and the PCR protocol as described above. PCR products from this amplification were purified using $\mathrm{LiCl}$ and ethanol as described above. Cloning of these PCR products and sequencing was carried out according to van der Maarel et al. (1998). PCR products were ligated into the $\mathrm{p}$-GEM-T vector and ligation products were cloned in $\mathrm{CaCl}_{2}$ competent Escherichia coli cells. For each band, the plasmids from 5 transformants were isolated. Plasmid inserts were amplified using the universal primers with a GC clamp. The resulting PCR products were run on a gradient gel together with PCR products from the original microbial community from which bands had been excised. Only those clones that yielded bands corresponding to the position where they had been cut from the original gradient gel were used for further analysis.

Phylogenetic analysis. Preliminary determination of the phylogenetic affiliation of the clones consisted of a BLAST (Altschul et al. 1990) analysis with the National Center for Biotechnology Information database. A number of sequences from the BLAST similarity ranking list were chosen for detailed phylogenetic analysis. The clone sequences were aligned with those from the database with the Dedicated Comparative Sequence
Editor software program of de Rijk \& de Wachter (1993). Phylogenetic trees and bootstrap analysis (100 replicates) were performed with the TREECON software package by the algorithm described by Kimura (van de Peer \& de Wachter 1994) and the neighbor joining method (Saitou \& Nei 1987).

Nucleotide sequence accession number. The nucleotide sequences of the $16 \mathrm{~S}$ rDNA clones MPD-1 to MPD-10 that were discussed in this study have been deposited into GenBank and were assigned accession numbers AF196555 to AF196564.

\section{RESULTS}

\section{DGGE profiles during mucus degradation in an enrichment culture}

The population dynamics in an enrichment culture degrading mucopolysaccharides were analyzed to reveal a possible correlation between the composition of the microbial community and the rate and extent of polymer degradation that was described in a previous paper (Janse et al. 1999). In that paper, we reported on mucopolysaccharide degradation in a number of stable enrichment cultures that had been inoculated with inocula from different origins. These enrichments were considered stable if the ability to degrade Phaeocystis mucopolysaccharides continued when a portion of the culture was transferred into fresh medium. From one of these stable enrichment cultures (originally inoculated with seawater from the Marsdiep, Dutch Wadden Sea, obtained May 8, 1996), samples were taken at several intervals (indicated by arrows in Fig. 1A) following transfer of a portion of the culture into new medium containing mucopolysaccharides. Cells were harvested for DGGE analysis, and the carbohydrate concentration was monitored in the culture supernatant. Fig. 1A depicts carbohydrate concentration versus incubation time. In the beginning, the mucopolysaccharide degradation rate was high, but it slowed down considerably to less than $5 \%$ of its original value after about $30 \mathrm{~d}$. After extraction of DNA from the collected cells, PCR amplifications with universal eubacterial primers were performed, and the amplification products were separated on a denaturing gradient gel. The resulting banding pattern provides a graphical representation of the composition of the bacterial community. The DGGE profiles from the microbial community on the days indicated in Fig. 1A are given in Fig. 1B. In the course of the $112 \mathrm{~d}$ incubation period several subtle changes in the banding profiles were observed. These changes were most pronounced from Day 29 onward. Interestingly, emerging or disappearing bands could still be observed at the very end of the 
incubation period (Days 97 and 112), when no further mucus breakdown could be detected (Fig. 1A). Therefore it is unlikely that these latter changes in banding profiles are directly related to mucopolysaccharide degradation.

\section{Comparison of DGGE profiles from different mucus degrading enrichments}

The complex banding patterns that were observed in the DGGE profiles from the above enrichments

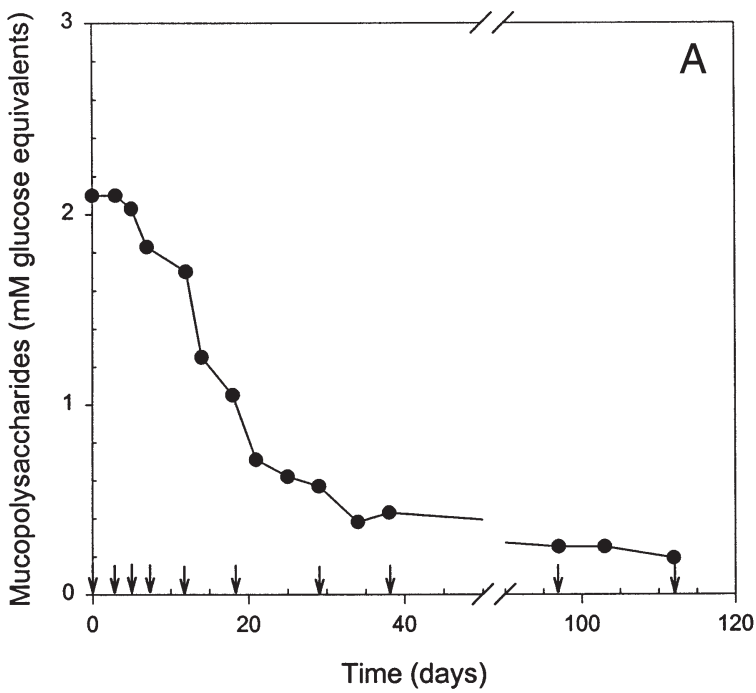

Days of incubation

B

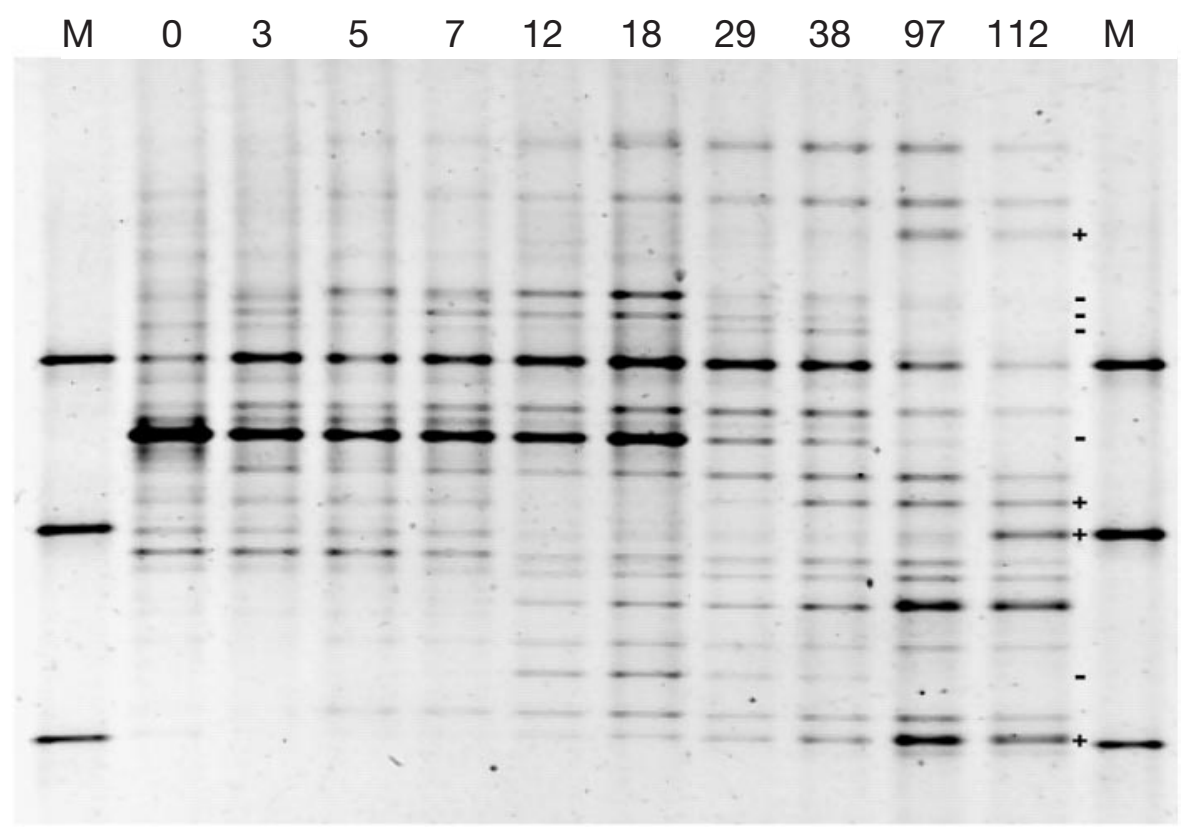

Fig. 1. Community composition of the microbial community in an enrichment culture (originally inoculated with seawater from the Dutch Wadden Sea) during degradation of Phaeocystis mucopolysaccharides. (A) Carbohydrate concentrations in the culture supernatant were measured at regular intervals. Arrows indicate the number of days after incubation at which the bacterial community was analyzed using DGGE. (B) Numbers represent days at which samples were collected; M: marker (DNA isolated from pure cultures of Lactococcus lactis, Micrococcus luteus and Escherichia coli, from top to bottom, amplified under identical conditions as enrichment DNA). A position in the gel where the intensity of a band becomes higher is indicated with + , a lower intensity with -. The $8 \%$ (w/v) polyacrylamide gel had a linear gradient ranging from 30 to $60 \%$ denaturant (100\% contained $7 \mathrm{M}$ urea and $40 \%$ formamide) 
(Fig. 1B) led to the question of whether these patterns reflected a discernable microbial (sub)community that was established as a result of the selection pressure imposed by a medium containing mucopolysaccharide as the carbon source. The substantial number of bands in the DGGE profiles indicated that an array of different bacteria was able to grow in these enrichments. However, as there were several possible substrates in the enrichment cultures as minor components of the mucopolysaccharide preparation (e.g. non-carbohydrate constituents of the semi-purified mucus, bacterial lysis products), it is likely that several members of the microbial community did not utilize mucopolysaccharides.

Using DGGE, a comparison was made between a number of stable enrichment cultures degrading Phaeocystis mucus, which were maintained at $12^{\circ} \mathrm{C}$ and which differed only with respect to the origin of their first inoculum (Fig. 2). Naturally, additional differences existed between anaerobic and aerobic enrichments with respect to the presence of oxygen and medium composition. These enrichments had originally been inoculated with bacteria from the water column (lanes 1 and 3 ) and sediment (lanes 5 and 6) collected at 2 different places in the Wadden Sea (the Netherlands) and from the water column (lane 4) and sediment (lanes 2, 7 and 8) in the Balsfjord (Norway). Samples for DGGE analysis were taken after 16 and $70 \mathrm{~d}$ of growth on mucopolysaccharides. Although the rate and extent of mucopolysaccharide degradation were comparable in these different enrichment cultures (data not shown), the composition of the microbial communities appeared to differ considerably. Out of more than 10 readily detectable bands obtained from the oxic enrichment cultures (lanes 1 to 4 ), only 3 bands were present at corresponding positions in the different enrichments (though not always after 16 and after $70 \mathrm{~d}$ of growth). A similar degree of heterogeneity was apparent in the anoxic enrichments (lanes 5 to 8) with not more than 3 corresponding bands. Differences in intensity of corresponding bands between the 2 timepoints (16 and $70 \mathrm{~d}$ ) at which samples had been taken from the oxic enrichments (lanes 1 to 4 ) were probably mainly due to variation in the total amount of PCR

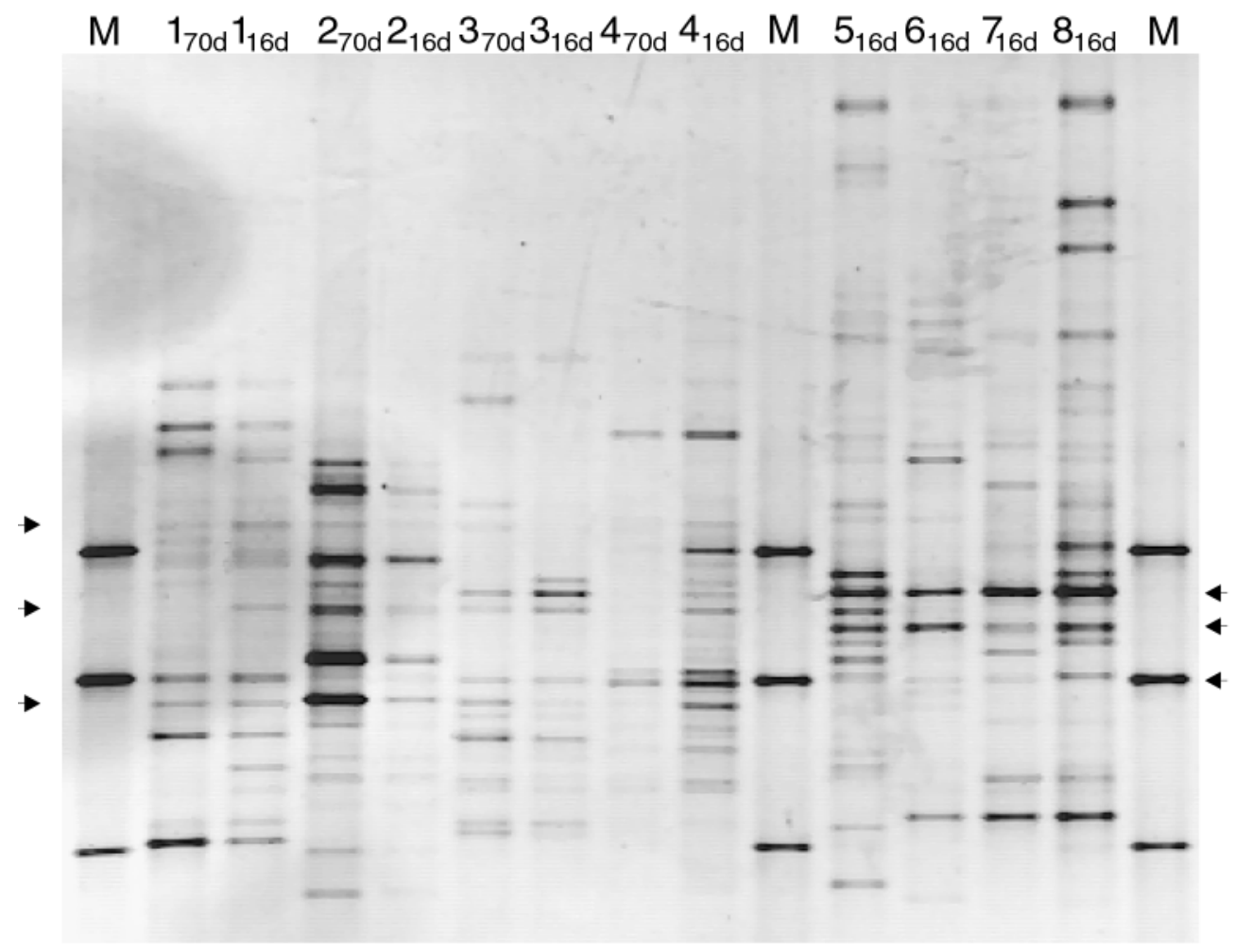

Fig. 2. Lanes 1 through 8 represent DGGE profiles of enrichments originally obtained from the following sources; lanes 1 and 3 : water column in the Marsdiep region, Wadden Sea (the Netherlands); lanes 5 and 6: sediment in the Marsdiep region; lane 4: water column in the Balsfjord (Norway); lanes 2, 7 and 8: sediment in the Balsfjord. Enrichments in lanes 1 to 4 were grown under oxic conditions, and in lanes 5 to 8 under anoxic conditions. The patterns shown were obtained with DNA extracted from the enrichments after 16 or $70 \mathrm{~d}$ of growth. Arrows on the left side indicate positions of bands that are present in all oxic enrichments of different origin (lanes 1 to 4); arrows on the right point to positions of bands that are present in the anoxic enrichments (lanes 5 to 8 ). M: marker as in legend to Fig. 1. Gradient gel as in legend to Fig. 1 
products that had been loaded on the gel. The sum of the intensities of all bands in a lane varied considerably between lanes (e.g. was very low for lanes 3 and 4), which implies that for interpretation of differences between individual bands differences in total intensity have to be taken into account.

\section{Identification of bacteria responsible for mucus degradation}

In order to characterize the bacteria responsible for mucopolysaccharide degradation, various attempts were made to isolate pure cultures from active enrichments via 'classical' methods based on growth in liquid culture and streaking on plates. Different types of solidified media were used to obtain growth of separate colonies. These included basic seawater medium containing a mixture of mono- and disaccharides or mucus as the carbon source, solidified with different agents. However, single colonies or mixtures of different colonies transferred from these plates to liquid media containing partially purified mucus invariably failed to yield mucusdegrading cultures. Also, in enrichments diluted to extinction, no mucopolysaccharide degradation occurred in the highest dilutions that still contained bacteria. In 2 of these enrichments breakdown was undetectable when the bacterial population from the original enrichment was diluted beyond 50 to 400 bacteria tube ${ }^{-1}$. These data suggested that the percentage of bacteria essential for degradation in the enrichment populations was between $2 \%$ (at least $1 / 50$ of the population constituting of degraders would be in accordance with the number of bacteria in the furthest diluted tubes with activity in both dilution series) and $2.5 \%$ (only activity in less than $1 / 40$ of the population would explain prevention of activity through dilution).

As the various attempts to obtain mucopolysaccharide-degrading isolates were not successful, another approach was used to identify the bacteria primarily involved in this process. The basis for this approach was the observation that incubation at an elevated temperature prevented mucopolysaccharide breakdown and that this was paralleled by the absence of certain bands from DGGE profiles of such cultures. In 2 enrichments that had originally been inoculated with seawater collected during blooms in the Wadden Sea and in the Balsfjord, and which had
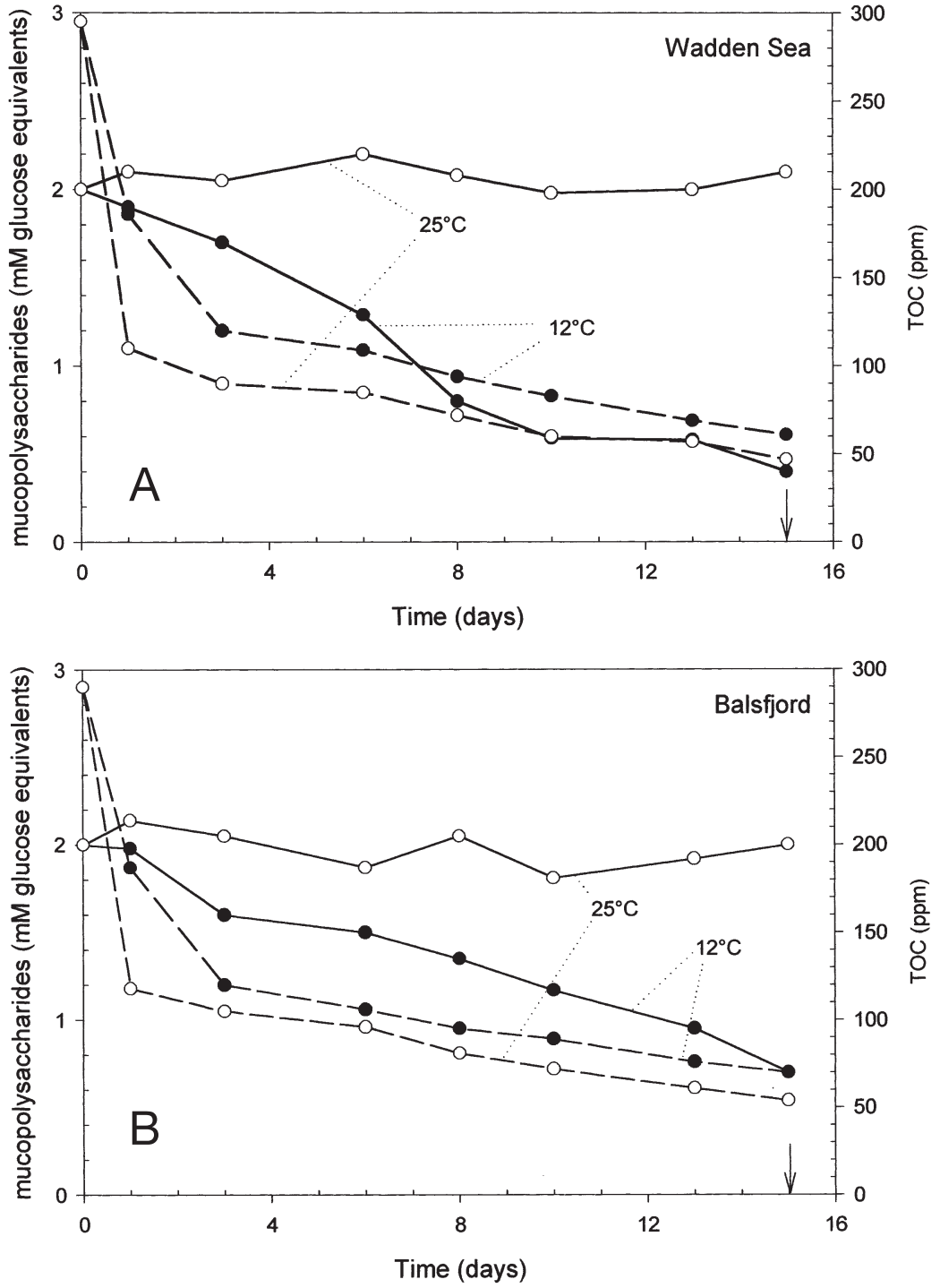

Fig. 3. Degradation of mucopolysaccharides and yeast extract at different temperatures. Two different enrichment cultures, originating from (A) the Wadden Sea and (B) the Balsfjord were transferred into medium containing partially purified Phaeocystis mucus (solid line) or yeast extract (dashed line) and incubated at $12^{\circ} \mathrm{C}(\bullet)$ or $25^{\circ} \mathrm{C}(\mathrm{o})$. Carbohydrate concentration (enrichments containing mucus) or total carbon concentration (enrichments containing yeast extract) in the supernatant were measured at regular intervals. Arrows indicate the point in time when bacteria from the enrichment cultures were harvested for DGGE analysis

been fully adapted to the degradation of mucopolysaccharides at $12^{\circ} \mathrm{C}$, breakdown of mucus proceeded as shown in Fig. 3A,B (solid lines). When these same enrichments were incubated at $25^{\circ} \mathrm{C}$, many bands disappeared from the DGGE profiles or lost most of their intensity after $15 \mathrm{~d}$ of incubation (Fig. 4A,B, compare second and third lanes). These data suggest that incubation at $25^{\circ} \mathrm{C}$ inhibits growth of certain bacteria, of which at least some are responsible for an essential 
step in mucopolysaccharide degradation. Yet, because bacteria growing in the enrichment cultures on substrates other than mucopolysaccharides may be inhibited at $25^{\circ} \mathrm{C}$ as well, the absence of a band at $25^{\circ} \mathrm{C}$ per se is not sufficient proof for the involvement of the corresponding species in mucopolysaccharide degradation. For this reason, inocula from stable mucopolysaccharide degrading enrichments were transferred to media with yeast extract instead of partially purified mucus as the only carbon source. In this way, bacteria not involved in mucopolysaccharide degradation should be stimulated most. Yeast extract was chosen to mimic the mixture of complex substrates present in the semi-purified mucus besides mucopolysaccharides, such as algal and bacterial lysis products.

Utilization of yeast extract was monitored by measuring TOC concentrations (Fig. 3A,B, dashed lines). Bacteria were harvested after $15 \mathrm{~d}$ of incubation and their community structure was analyzed using DGGE (Fig. 4A,B). Only those bacteria that were dominant in enrichment cultures containing mucopolysaccharides at $12^{\circ} \mathrm{C}$, but not at $25^{\circ} \mathrm{C}$, or when yeast extract was the sole carbon source, were considered to play a role in mucopolysaccharide degradation.

Whereas many bands from cultures growing on yeast extract appeared to overlap with those from

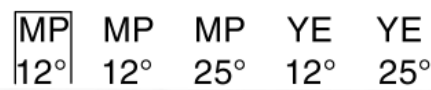

A

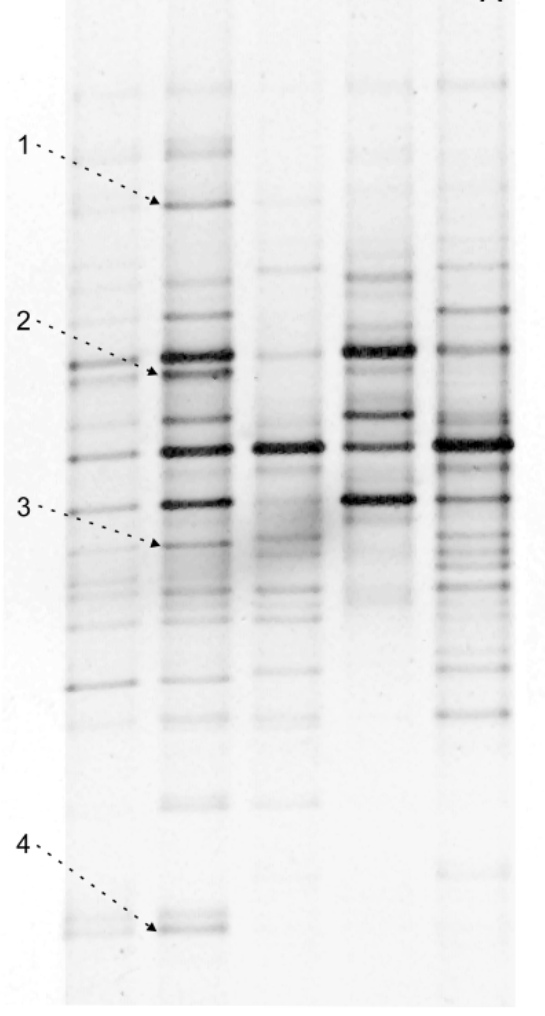

MP MP MP YE YE

$12^{\circ} 12^{\circ} 25^{\circ} 12^{\circ} 25^{\circ}$

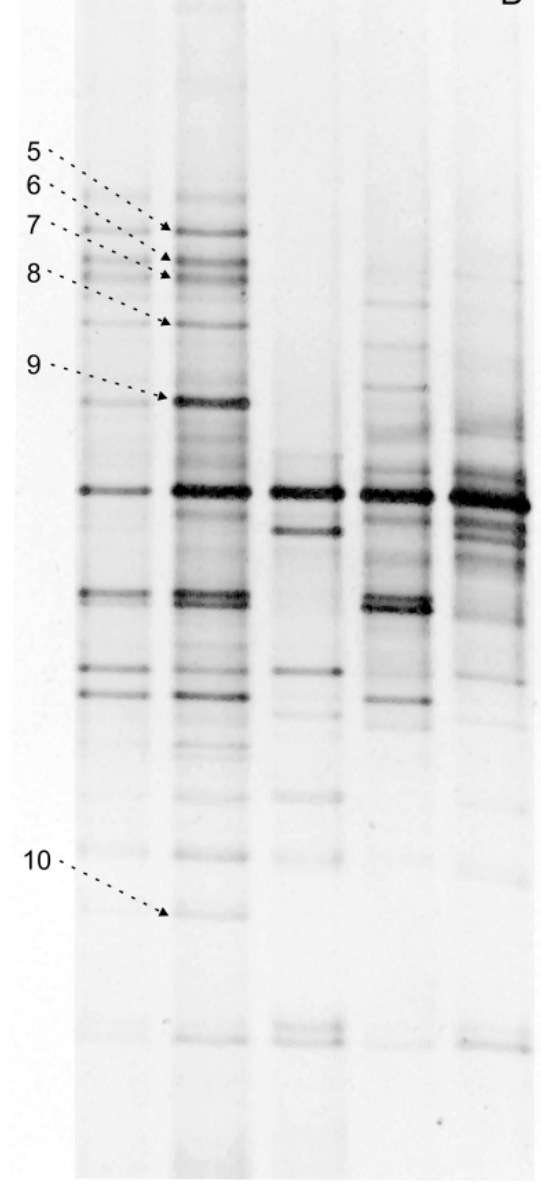

Fig. 4. Composition of the microbial community in the enrichment cultures shown in Fig. 3. Bacteria from the enrichment cultures originating from (A) the Wadden Sea and (B) the Balsfjord were harvested for DGGE analysis at the start of incubation and after $15 \mathrm{~d}$ (indicated by arrows in Fig. 3). DGGE profiles in the very first lanes of both (A) and (B) correspond to the enrichment cultures at the start of the incubations. Profiles after $15 \mathrm{~d}$ of incubation under various conditions are given in the subsequent 4 lanes. MP: incubation with mucopolysaccharides as carbon source; YE: incubation with yeast extract as carbon source; incubation temperatures are 12 and $25^{\circ} \mathrm{C}$. Numbers 1 to 10 refer to bands that were excised from the gel, amplified, cloned and sequenced. These clones were given the codes MPD-1 to MPD-10. The $8 \%(\mathrm{w} / \mathrm{v})$ polyacrylamide gel had a linear gradient ranging from 40 to $55 \%$ denaturant ( $100 \%$ contained $7 \mathrm{M}$ urea and $40 \%$ formamide) 
mucus-degrading enrichment cultures, some were exclusively present after growth on either one of these substrates. From the DGGE gel of the 2 different enrichment cultures (Fig. 4A,B) 10 bands that met the criteria mentioned above (bands 1 to 4 from Fig. 4A, and 5 to 10 from Fig. 4B) were excised and the DNA fragments were re-amplified and cloned. The partial 16S rRNA gene inserts of these clones were sequenced and a phylogenetic analysis was performed on these sequences (Fig. 5). The various clones appeared to align with 4 clusters: the Cytophaga-Flexibacter, the $\gamma$-Proteobacteria, the $\alpha$-Proteobacteria, and the Planctomyces and Verrucomicrobiales. The sequences of 2 DNA fragments that were present at similar positions in the DGGE profiles from the Wadden Sea (Fig. 4A) and the Balsfjord (Fig. 4B) enrichments were identical (clones MPD-1 vs MPD-5, and MPD-2 vs MPD-9, respectively).

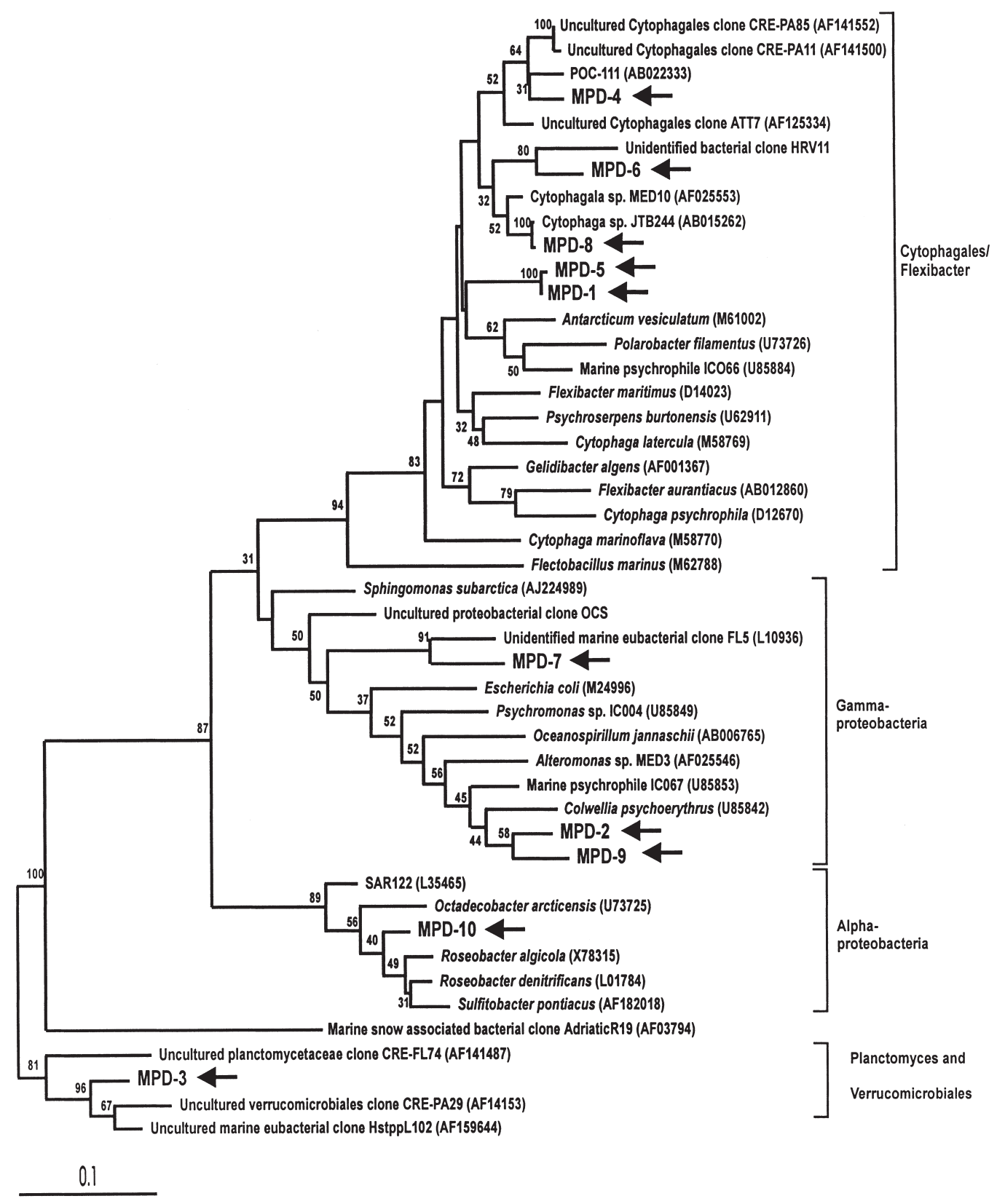

Fig. 5. Phylogenetic tree showing relationships of the sequences of clones MPD-1 to MPD-10 from Fig. 4 to representative bacterial 16S rRNA. Sequences from cultured bacteria and from environmental clones were retrieved from GenBank, accession numbers are in brackets. The tree was constructed by the neighbor joining method and using the DCSE alignment program. Numbers indicate absolute bootstrap values per 100 bootstraps performed. Scale bar indicates substitutions per nucleotide position 


\section{DISCUSSION}

\section{Microbial community dynamics in mucopoly- saccharide-degrading enrichments}

During spring blooms, mucus exudated by Phaeocystis constitutes an important source of organic carbon (Lancelot \& Mathot 1987, Weisse \& Scheffel-Möser 1990, Thingstad \& Billen 1994). However, after the blooming period, mucopolysaccharides disappear and are virtually absent from the water column for the rest of the year. Provided that only specific bacteria have the ability to utilize mucopolysaccharides, the fluctuating release of mucopolyaccharides represents a way in which the algal bloom significantly influences the composition of the marine microbial community during part of the year. A couple of findings seem to support the idea that Phaeocystis mucopolysaccharides are degraded by specialized bacteria whose abundance is correlated with bloom development. First of all, the complex monosaccharide composition of the mucopolysaccharides (Janse et al. 1996, 1999) suggests that specialized enzymes are required for breakdown. Secondly, the absence of bacteria on Phaeocystis colonies during early bloom stages (Davidson \& Marchant 1987 , Lancelot \& Rousseau 1994, Thingstad \& Billen 1994) and the lag phase observed between bloom development and growth of bacteria (Laanbroek et al. 1985, Veldhuis et al. 1986, Billen \& Fontigny 1987) can be interpreted as the need for a specifically adapted bacterial community, which is established only in response to the formation of large quantities of Phaeocystis mucopolysaccharides. Finally, the absence of mucopolysaccharide degraders during part of the year may explain the failure to yield mucus-degrading enrichments from inocula collected several months before the start of the spring bloom (Janse et al. 1999). The occurrence of such seasonal changes in species abundance within the bacterioplankton, similar to the seasonal succession in phytoplankton communities (Begon et al. 1990), has been recorded before (Lee \& Fuhrman 1990, Rehnstam et al. 1993, Øvreås et al. 1997, Pinhassi et al. 1997, Murray et al. 1998).

In the analysis of the DGGE profiles there is not necessarily a direct correlation between the intensity of a band in a DGGE profile and the absolute abundance of the corresponding bacterium in the original sample. The PCR amplification reaction may introduce possible biases such as chimera formation (Kopczynski et al. 1994, Wang \& Wang 1997), heteroduplex formation (Ferris \& Ward 1997), template annealing (Suzuki \& Giovanni 1996), and preferential amplification of some DNA templates (Reysenbach et al. 1992). In addition, differences in genome size and number of 16S rRNA genes among bacteria (Farelly et al. 1995) make strictly quantitative interpretations questionable. Nevertheless, as the DGGE profiles in Fig. 1B were obtained under identical conditions from the same enrichment culture, shifts in microbial community structure are likely to show up as changes in relative intensities of bands. If a bias in DNA isolation or amplification exists, this would be relatively constant, making comparison of the banding pattern reliable. The constant patterns during the first $18 \mathrm{~d}$ in which the major part of the mucopolysaccharides were degraded support this view and seem to correspond well with the earlier reported constant composition during breakdown (Janse et al. 1999). These findings argue against a succession of different bacterial populations attacking different fractions of the complex substrate. Rather, the degradation is likely to depend on one or several bacteria whose activities are closely coupled.

The intensity of some bands appeared to remain unaltered irrespective of the occurrence of mucus breakdown, i.e. including a period of $80 \mathrm{~d}$ following Day 30, during which no further breakdown was observed. This could indicate that the corresponding bacteria are not dependent on mucus for their growth and used other substrates. These other compounds could be the non-mucopolysaccharide fraction that constitutes part of the partially purified mucus (Janse et al. 1999), or lysis products of bacteria in the enrichment. Some bands that increased in intensity long after breakdown had halted are also likely to originate from bacteria which grew on lysis products. Other bands that disappeared entirely after Day 38 could indicate involvement of the corresponding bacteria in degradation of the mucopolysaccharides. Interestingly, a number of enrichment cultures on partially purified mucus, which had been inoculated from different sources, showed similar mucus breakdown patterns although different microbial communities had established themselves in these enrichments (Fig. 2). This heterogeneity in community composition, despite enrichment on one and the same substrate, suggests that mucopolysaccharide degradation is a process not requiring a specifically adapted microbial community, but rather can be performed by many species of bacteria. It is possible that the few bands that overlapped between enrichments were derived from bacteria specifically involved in degradation of the mucus, whereas the other bands reflect the presence of bacteria that grow on mucopolysaccharide degradation products or lysis products. Such less specialized substrates would stimulate growth of many types of bacteria and the resulting enrichment communities would therefore be largely dependent on the species present in the initial inoculum, which is determined by the spatial and temporal variations within the marine microbial community. 


\section{Attempts to isolate pure cultures of mucopoly- saccharide-degrading bacteria}

Lack of success in obtaining pure cultures of bacteria that are capable of mucopolysaccharide degradation may be explained in a number of ways. Dilution to extinction from enrichments will only yield pure cultures of the most abundant bacteria. This isolation strategy would never yield pure cultures of mucopolysaccharide degraders, since our dilution series indicated that mucopolysaccharide degradation did not occur in the highest dilutions which still contained bacteria. Apparently, bacteria essential for mucopolysaccharide degradation constituted only a minor fraction (approx. $2 \%$ ) of the population in enrichments. The inability of the majority of bacteria to form colonies when placed directly on solid culture media has often been reported (Ward et al. 1990, Santegoeds et al. 1996, Ward et al. 1997, Schut et al. 1997a,b). Possible causes for this phenomenon include the specific conditions provided by solidified medium, the production of inhibitors or the action of viruses (Rehnstam et al. 1993, Schut et al. 1997b). The possibility that lack of growth in our plates was caused by inhibiting compounds present in the agar was minimized by using different solidifying agents. An explanation for the lack of degradation after transfer of colonies from plates into liquid medium would be that the consorted action of several strains (that do grow on plates) is needed for growth on mucopolysaccharides. However, as the transfer of a mixture of different colonies including those from the most undiluted area on the plates into medium containing partially purified mucus also did not lead to mucopolysaccharide breakdown, this possibility is not very likely. In conclusion, the isolation attempts suggested that essential members of the mucus-degrading communities were not abundant in the enrichments and could not grow on solid medium.

\section{Identification of putative mucopolysaccharide degraders using DGGE}

Our approach towards identifying mucopolysaccharide-degrading bacteria was based on DGGE. The clones that we sequenced were derived from DGGE bands corresponding with bacteria that were considered to be involved in Phaeocystis mucopolysaccharide degradation. Selection of these bands was based on differences in microbial community composition as a result of different incubation temperatures. DGGE has been used to study temperature dependence of the microbial community composition in enrichments before (e.g. Ward et al. 1997), but unique to our experiments is the correlation that was found with a physio- logical characteristic of the population, i.e. mucopolysaccharide degradation.

The sequences of the 10 selected bands from Fig. 4 revealed that 2 of the DNA fragments at similar positions in the DGGE profiles of the 2 different enrichments were identical. As these 2 enrichment cultures were of different origin (Wadden Sea and Balsfjord), the bacteria from which these bands originated were the most likely candidates to perform an essential step in mucopolysaccharide degradation. The use of $170 \mathrm{bp}$ fragments for DGGE causes limitations on the resolution of phylogenetic analysis. However, phylogenetic analysis based on such partial sequences have been found to be largely congruent with those calculated using most of the 16S gene (Schmidt et al. 1991, Rath et al. 1998). The 10 selected sequences were distributed in 4 major groups (the $\alpha$ and $\gamma$ subdivisions of the Proteobacteria, the Cytophaga/Flexibacter cluster, and the Planctomyces and Verrucomicrobiales clade), which harbor very different bacterial species.

Two assumptions need to be made to validate our approach. Firstly, the inhibiting effect of the elevated temperature is brought about by growth inhibition of bacteria specialized in mucopolysaccharide degradation. In other words, bacteria degrading mucopolysaccharides in the enrichments at $12^{\circ} \mathrm{C}$ did not simply switch to another growth substrate after transfer into fresh mucopolysaccharide-containing medium and incubation at $25^{\circ} \mathrm{C}$. Secondly, yeast extract is more effective in stimulating growth of bacteria using substrates other than mucopolysaccharides than growth of mucopolysaccharide degraders. Both assumptions presume the existence of mucopolysaccharide 'specialists', which are outcompeted by other bacteria when grown together on substrates less complex than mucopolysaccharides. The existence of specialists that become abundant when stimulated by mucopolysaccharides is supported by some field observations (for references see first part of the 'Discussion').

When enrichments adapted to growth on partially purified mucus as the carbon source were grown with yeast extract, no 'new' bands appeared. Apparently, changing the growth substrate did not result in growth of bacteria that remained undetected on mucus. This finding, together with the reported sensitivity of $1 \%$ (bacterial population representing $1 \%$ of total community is still detectable with DGGE) for eubacterial primers (Muyzer et al. 1993), supports the idea that most bacteria present in the enrichment show up in the DGGE profiles. Therefore, incubation with yeast extract induced changes in the relative abundance of bacteria already present in the mucopolysaccharidedegrading enrichments, rather than stimulating growth of previously undetected bacteria. Nevertheless, there remains the possibility of misidentification 
of psychrophylic bacteria growing on substrates other than mucopolysaccharides at $12^{\circ} \mathrm{C}$, which are inhibited at $25^{\circ} \mathrm{C}$ and are not stimulated by yeast extract.

\section{Relevance of the findings from enrichment cultures for the natural situation}

As the stable enrichments that were used in our experiments were transferred in batch cultures after mucus had been degraded, selection will have favored the fastest growing bacteria of which at least some are capable of mucopolysaccharide degradation. However, whether these also play a dominant role in mucopolysaccharide degradation in the natural environment remains to be seen. Populations sampled by cultivation are usually very different from what is revealed by direct analysis using molecular methods (Ward et al. 1990, 1997, Bennloch et al. 1995, Ferris et al. 1996, Santegoeds et al. 1996). Also in our enrichments, conditions such as incubation temperature or substrate and nutrient concentrations could have selected for different bacteria than those that play a dominant role in the natural situation.

Current data are too scarce to make firm inferences regarding the physiology of the identified strains. Yet the sequences related most closely to our clones were in most cases derived from cold biota, e.g. Colwellia psychroerythrus, closest to the identical clones MPD-2 and MPD-9, Antarcticum vesiculatum, Polarobacter filamentus, and marine psychrophile ICO66, closest to the identical clones MPD-1 and MPD-5, which were derived from Antarctic sea-ice and lake environments. Representatives of the Cytophaga are known to degrade complex organic molecules, e.g. lignin and cellulose (Shewan \& McMeekin 1983). In a study in the Southern Ocean, bacteria from the Cytophaga/ Flavobacterium cluster were found to be very abundant during a Phaeocystis bloom and comprised $72 \%$ of the DAPI counts (Simon et al. 1999). Our present findings now link representatives of these abundant marine picoplankton groups to the degradation of Phaeocystis mucopolysaccharides, thus providing a possible explanation for their abundance.

The choice for universal, eubacterial primers excluded the detection of Archaea in the enrichment cultures. Although Archaea have been reported to constitute a significant portion of the picoplankton in the oceans (DeLong et al. 1994), they have been found mainly in winter and in deeper water layers and with decreasing proportions towards summer and phytoplankton blooms (DeLong et al. 1994, Massana et al. 1998, Murray et al. 1998). During a Phaeocystis bloom in the Southern Ocean, Archaea were not detected (Simon et al. 1999).

\section{Conclusion}

In this paper we have shown that the composition of the microbial communities in enrichments degrading Phaeocystis mucopolysaccharides is rather diverse, with only few overlapping members between enrichments from different sources. Despite the failure to isolate pure cultures of mucopolysaccharide degraders, bacteria likely involved in the degradation could be identified. To this end, the correlation between the occurrence of mucopolysaccharide degradation and the presence of specific bands in DGGE profiles were used. Assumptions claiming mucopolysaccharide degradation to be a process executed by specialized bacteria needed to be made. This study provides a good example of the identification of marine bacteria that were selected for their role in degradation of an abundant and complex naturally occurring algal biopolymer. A next step would be to confirm that the identified bacteria indeed play their predicted role in the sea. Using DGGE or specific probes throughout different blooms the possibly unique association of these bacteria with Phaeocystis could be further investigated.

Acknowledgements. Paul Wassmann and his research group at the Norwegian College of Fishery Science (NFH), University of Tromsø, Norway, are gratefully acknowledged for the opportunity to join the 1996 spring bloom field campaign in the Balsfjord. We thank Riks Laanbroek for access to the laboratory facilities of the Netherlands Instituite of Ecology, Centre for Limnology (NIOO-CL), Nieuwersluis, The Netherlands. Larry J. Forney is acknowledged for critically reading the manuscript.

\section{LITERATURE CITED}

Altschul SF, Gish W, Miller W, Myers EW, Lipman DJ (1990) Basic local alignment search tool. J Mol Biol 215:403-410 Azam F, Smith DC, Long RA, Steward GF (1995) Bacteria in oceanic carbon cycling as a molecular problem. In: Joint I (ed) Molecular ecology of aquatic microbes. NATO ASI Series Vol G 38, Springer-Verlag, Berlin, p 39-54

Begon M, Harper JL, Townsend CR (1990) Ecology. Blackwell, Boston, p 514-520

Benner R, Pakulski JD, McCarthy M, Hedges JI, Hatcher PG (1992) Bulk characteristics of dissolved organic matter in the ocean. Science 255:1561-1564

Bennloch S, Martínez-Murcia JA, Rodríguez-Valera F (1995) Sequencing of bacterial and archaeal 16S rRNA genes directly amplified from a hypersaline environment. Syst Appl Microbiol 18:574-581

Billen G, Fontigny A (1987) Dynamics of Phaeocystis dominated spring bloom in Belgian coastal waters. II. Bacterioplankton dynamics. Mar Ecol Prog Ser 37:249-257

Cole JJ, Findlay S, Pace M (1988) Bacterial production in salt and freshwater ecosystems: a cross-system overview. Mar Ecol Prog Ser 43: 1-10

Davidson AT, Marchant HJ (1987) Binding of manganese by Antarctic Phaeocystis pouchetii and the role of bacteria in its release. Mar Biol 95:481-487

Davidson AT, Marchant HJ (1992) The biology and ecology of 
Phaeocystis (Prymnesiophyceae). Prog Phycol Res 8:1-45

DeLong EF, Wu KY, Prézelin BB, Jovine RVM (1994) High abundance of Archaea in Antarctic marine picoplankton. Nature 371:695-697

de Rijk P, de Wachter R (1993) DCSE v2.54, an interactive tool for sequence alignment and secondary structure research. Comput Applic Biosci 9:735-740

Druffel ERM, Williams PM, Bauer JE, Ertel R (1992) Cycling of dissolved and particulate organic matter in the open ocean. J Geophys Res 97:639-659

Farrelly V, Rainey FA, Stackebrandt E (1995) Effect of genome size and rrn gene copy number on PCR amplification of 16S rRNA genes from a mixture of bacterial species. Appl Environ Microbiol 61:2798-2801

Ferris MJ, Ward DM (1997) Seasonal distributions of dominant 16S rRNA-defined populations in a hot spring microbial mat examined by denaturing gradient gel electrophoresis. Appl Environ Microbiol 63:1375-1381

Ferris MJ, Ruff-Roberts AL, Kopczynsky ED, Bateson MM, Ward DM (1996) Enrichment culture and microscopy conceal diverse thermophilic Synochococcus in a single hot spring mat habitat. Appl Environ Microbiol 62:1045-1050

Fuhrman JA (1992) Bacterioplankton roles in the cycling of organic matter: the microbial food web. In: Falkowski PG, Woodhead AD (eds) Primary productivity and biogeochemical cycles in the sea. Plenum Press, New York, p 361-383

Fuhrman JA, Azam F (1982) Thymidine incorporation as a measure of heterotrophic bacterioplankton production in marine surface waters. Mar Biol 66: 109-120

Gerhardt P, Murray RGE, Wood WA, Krieg NR (1994) Methods for general and molecular bacteriology. American Society for Microbiology, NW Washington, DC

Hagström Å, Azam F, Andersson A,Wikner J, Rassoulzadegan, F (1988) Microbial loop in an oligotrophic pelagic marine ecosystem: possible roles of cyanobacteria and nanoflagellates in the organic fluxes. Mar Ecol Prog Ser 49:71-178

Hong Y, Smith WO Jr, White AM (1997) Studies on transparent exopolymer particles (TEP) produced in the Ross Sea (Antarctica) and by Phaeocystis antarctica (Prymnesiophyceae). J Phycol 33:368-376

Janse I, van Rijssel M, Gottschal JC, Lancelot C, Gieskes WWC (1996) Carbohydrates in the North Sea during spring blooms of Phaeocystis: a specific fingerprint. Aquat Microb Ecol 10:97-103

Janse I, van Rijssel M, Ottema A, Gottschal JC (1999) Microbial degradation of Phaeocystis mucopolysaccharides. Limnol Oceanogr 44(6):1447-1457

Kopczynski ED, Bateson MM, Ward DM (1994) Recognition of chimeric small-subunit ribosomal DNAs composed of genes from uncultivated microorganisms. Appl Environ Microbiol 60:746-748

Laanbroek HL, Verplanke JC, de Visscher PRM, de Vuyst R (1985) Distribution of phyto- and bacterioplankton growth and biomass parameters, dissolved inorganic nutrients and free amino acids during a spring bloom in the Osterschelde basin, The Netherlands. Mar Ecol Prog Ser 25:1-11

Lalli CM, Parsons TR (1993) Biological oceanography: an introduction. Pergamon Press, Oxford

Lancelot C, Mathot S (1987) Dynamics of a Phaeocystis-dominated spring bloom in Belgian coastal waters. I. Phytoplankton activity and related parameters. Mar Ecol Prog Ser 37:239-248

Lancelot C, Rousseau V (1994) Ecology of Phaeocystis dominated ecosystems: the key role of colony forms. In: Lead- beater B, Green J (eds) The prymnesiophyte algae. Syst Assoc, Spec Vol, Oxford University Press, Oxford, p 229-245

Lancelot C, Billen G, Sournia A, Weisse T, Colijn M, Veldhuis M, Davies A, Wassman P (1987) Phaeocystis blooms and nutrient enrichment in the continental coastal zone of the North Sea. Ambio 16:38-46

Lee S, Fuhrman JA (1990) DNA hybrydization to compare species compositions of natural bacterioplankton assemblages. Appl Environ Microbiol 56:739-746

Liu D, Wong PTS, Dutka BJ (1973) Determination of carbohydrate in lake sediment by a modified phenol-sulphuric acid method. Water Res 7:741-746

Massana R, Taylor LT, Murray AE, Wu KY, Jeffrey WH, DeLong EF (1998) Vertical distribution and temporal variation of marine plankton Archaea in the Gerlache Strait, Antarctica, during early spring. Limnol Oceanogr 43: 607-616

Murray AE, Preston CM, Massana R, Taylor LT, Blakis A, Wu KY, DeLong EF (1998) Seasonal and spatial variability of bacterial and archaeal assemblages in the coastal waters near Anvers Island, Antarctica. Appl Environ Microbiol 64:2585-2595

Muyzer G, de Waal EC, Uitterlinden AG (1993) Profiling of complex microbial populations by denaturing gradient gel electrophoresis analysis of polymerase chain reactionamplified genes coding for 16S rRNA. Appl Environ Microbiol 59:695-700

Øvreås L, Forney LJ, Daae FL, Torsvik V (1997) Distribution of bacterioplankton in meromictic lake Sælenvannet, as determined by denaturing gradient gel electrophoresis of PCR-amplified gene fragments coding for 16S rRNA. Appl Environ Microbiol 63(9):3367-3373

Pinhassi J, Zweifel UL, Hagström Å (1997) Dominant marine bacterioplankton species found among colony-forming bacteria. Appl Environ Microbiol 63(9):3359-3366

Rath J, Wu KY, Herndl GJ, DeLong EF (1998) High phylogenetic diversity in a marine-snow associated bacterial assemblage. Aquat Microb Ecol 14:262-269

Rehnstam AS, Bäckman S, Smith DC, Azam F, Hagström A (1993) Blooms of sequence-specific culturable bacteria in the sea. FEMS Microbiol Ecol 102:161-166

Reysenbach AL, Giver LJ, Wickham GS, Pace NR (1992) Differential amplification of rRNA genes by polymerase chain reaction. Appl Environ Microbiol 58:3417-3418

Rheinheimer G (1992) Aquatic microbiology, 4th edn. Wiley \& Sons, Chichester

Riebesell U, Reigstad M, Wassman P, Noji T, Passow U (1995) On the trophic fate of Phaeocystis pouchetii (hariot): VI. Significance of Phaeocystis-derived mucus for vertical flux. Neth J Sea Res 33(2):193-203

Saitou N, Nei M (1987) The neighbour-joining method: a new method for reconstructing phylogenetic trees. Mol Biol Evol 4:406-425

Sambrook J, Fritsch EF, Maniatis T (1989) Molecular cloning: a laboratory manual. Cold Spring Harbor Laboratory Press, Cold Spring Harbor, NY

Sanguinetti CJ, Dias Neto E, Simpson AJG (1994) Rapid silver staining and recovery of PCR products separated on polyacrylamide gels. Biotechniques 17(5):914-921

Santegoeds CM, Nold SC, Ward DM (1996) Denaturing gradient gel electrophoresis used to monitor the enrichment culture of aerobic chemoorganotrophic bacteria from a hot spring cyanobacterial mat. Appl Environ Microbiol 62(11): 3922-3928

Schlegel HG (1995) General microbiology, 7th edn. Cambridge University Press, Cambridge 
Schmidt TM, DeLong EF, Pace NR (1991) Analysis of marine picoplankton community by $16 \mathrm{~S}$ rRNA gene cloning and sequencing. J Bacteriol 173:4371-4378

Schut F, de Vries EJ, Gottschal JC, Robertson BR, Harder W, Prins RA, Button DK (1993) Isolation of typical marine bacteria by dilution culture: growth, maintenance and characteristics under laboratory conditions. Appl Environ Microbiol 59:2150-2160

Schut F, Gottschal JC, Prins RA (1997a) Isolation and characterisation of the marine ultramicrobacterium Sphingomonas sp. Strain RB2256. FEMS Microbiol Rev 20: 363-369

Schut F, Prins RA, Gottschal JC (1997b) Oligotrophy and pelagic marine bacteria: facts and fiction. Aquat Microb Ecol 12:177-202

Shewan JM, McMeekin TA (1983) Taxonomy (and ecology) of Flavobacterium and related genera. Annu Rev Microbiol 37:233-252

Simon M, Glöckner FO, Amann R (1999) Different community structure and temperature optima of heterotrophic picoplankton in various regions of the Southern Ocean. Aquat Microb Ecol 18:275-284

Sugimura Y, Suzuki Y (1988) A high-temperature catalytic oxidation method for the determination of non-volatile dissolved organic carbon in seawater by direct injection of a liquid sample. Mar Chem 24:105

Suzuki MT, Giovanni SJ (1996) Bias caused by template annealing in the amplification mixtures of 16S rRNA genes by PCR. Appl Environ Microbiol 62:625-630

Thingstad F, Billen G (1994) Microbial degradation of Phaeocystis material in the water column. J Mar Syst 5:55-65

van Boekel WHM (1993) Interactions of Phaeocystis sp. with organic compounds and the microbial food web. PhD thesis, University of Groningen

van de Peer Y, de Wachter R (1994) TREECON for windows: a software package for the construction and drawing of evolutionary trees for the microsoft windows environment. Comput Applic Biosci 10:569-570

van der Maarel MJEC, Artz RRE, Haanstra R, Forney LJ

Editorial responsibility: Frede Thingstad,

Bergen, Norway
(1998) Association of marine Archaea with the digestive tracts of two marine fish species. Appl Environ Microbiol 64:2894-2898

van Rijssel M, Hamm CE, Gieskes WWC (1997) Phaeocystis globosa (Prymnesiophyceae) colonies: hollow structures built with small amounts of polysaccharides. Eur J Phycol 32:185-192

Veldhuis MJW, Admiraal W (1987) The influence of phosphate depletion on the growth and colony formation of Phaeocystis pouchetii (Hariot) Lagerheim. Mar Biol 95: 47-54

Veldhuis MJW, Colijn F, Venekamp LAH (1986) The spring bloom of Phaeocystis pouchetii (haptophyceae) in Dutch coastal water. Neth J Sea Res 20: 37-48

Wang GCY, Wang Y (1997) Frequency of formation of chimeric molecules as a consequence of PCR coamplification of 16S rRNA genes from mixed bacterial genomes. Appl Environ Microbiol 63:4645-4650

Ward DM, Weller R, Bateson MM (1990) 16S rRna sequences reveal numerous uncultured microorganisms in a natural community. Nature 345:63-65

Ward DM, Santegoeds CM, Nold SC, Ramsing NB, Ferris MJ, Bateson MM (1997) Biodiversity within hot spring microbial mat communities: molecular monitoring of enrichment cultures. Antonie Leeuwenhoek 71: 143-150

Warren RAJ (1996) Microbial hydrolysis of polysaccharides. Annu Rev Microbiol 50:183-212

Weisse T, Scheffel-Möser U (1990) Growth and grazing loss rates in single-celled Phaeocystis sp. (Prymnesiophyceae). Mar Biol 106: 153-158

Williams PM, Druffel ERM (1987) Radiocarbon in dissolved organic matter in the North Pacific Ocean. Nature 330: 246-248

Zwart G, Huismans R, van Agterveld MP, van de Peer Y, de Rijk P, Eenhoorn H, Muyzer G, van Hannen EJ, Gons HJ, Laanbroek HJ (1998) Divergent members of the bacterial division Verrucomicrobiales in a temperate freshwater lake. FEMS Microbiol Ecol 25:159-169

Submitted: November 15, 1999; Accepted: June 15, 2000 Proofs received from author(s): July 17, 2000 